\title{
Stable isotopes and diet: their contribution to Romano-British research
}

Article

Muldner, G. (2013) Stable isotopes and diet: their contribution to Romano-British research. Antiquity, 87 (335). pp. 137-149. ISSN 0003-598X Available at https://centaur.reading.ac.uk/28535/

It is advisable to refer to the publisher's version if you intend to cite from the work. See Guidance on citing.

Published version at: http://antiquity.ac.uk/ant/087/ant0870137.htm

Publisher: Antiquity Publications

Publisher statement: (C2013 (C) Antiquity Publications Ltd

All outputs in CentAUR are protected by Intellectual Property Rights law, including copyright law. Copyright and IPR is retained by the creators or other copyright holders. Terms and conditions for use of this material are defined in the End User Agreement.

\section{www.reading.ac.uk/centaur}

\section{CentAUR}

Central Archive at the University of Reading

Reading's research outputs online 


\title{
Stable isotopes and diet: their contribution to Romano-British research
}

\author{
Gundula Müldner*
}

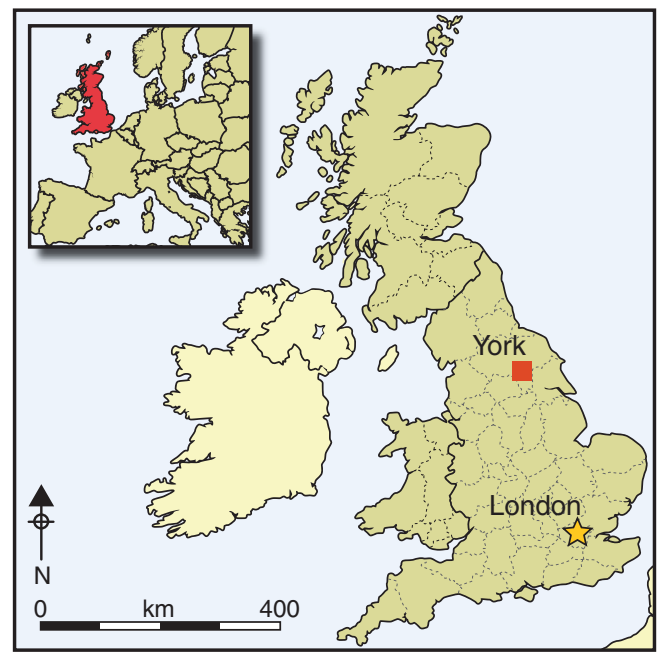

The study of stable isotopes surviving in human bone is fast becoming a standard response in the analysis of cemeteries. Reviewing the state of the art for Roman Britain, the author shows clear indications of a change in diet (for the better) following the Romanisation of Iron Age Britainincluding more seafood, and more nutritional variety in the towns. While samples from the bones report an average of diet over the years leading up to an individual's death, carbon and nitrogen isotope signatures taken from the teeth may have a biographical elementcapturing those childhood dinners. In this way migrants have been detected - as in the likely presence of Africans in Roman York. While not unexpected, these results show the increasing power of stable isotopes to comment on populations subject to demographic pressures of every kind.

Keywords: Roman Britain, isotope analysis, carbon, nitrogen, diet, culture change

Supplementary material is published online at www.antiquity.ac.uk/projgall/muldner335

\section{Introduction}

The Roman conquest of AD 43 is an important watershed in the history of Britain. It is traditionally regarded as the 'end of British prehistory' and marking the beginning of four centuries as part of a vast Mediterranean empire. Although the simplistic notion of 'Romanisation' in the sense of one-directional acculturation has now been all but deconstructed and replaced by more complex models of interaction (see Webster 2001; Mattingly 2004), exploring the many changes that occurred in the social, political and economic make-up of post-conquest Britain is still a productive approach towards a better understanding of the realities of life in Rome's northernmost province (see Mattingly 2006).

Department of Archaeology, University of Reading, Whiteknights, PO Box 227, Reading RG6 6AB, UK (Email: g.h.mueldner@reading.ac.uk) 
The analysis of food and foodways has proved a particularly fruitful approach in this respect. Investigations into different foods and the material culture associated with their production, distribution and consumption has demonstrated that the transition from the Iron Age to the Roman period brought with it a large number of changes, an increase in dietary breadth and the availability of exotic foods as well as changes in cooking and dining culture. By contrasting different site types, the evidence has also highlighted variation within society, with the greatest changes, unsurprisingly, seen in the larger towns and places associated with the military. The impact on rural Britain seems to have been much more varied, with some sites readily embracing the new foodways, while others appear more conservative, choosing to adapt (and possibly subvert) only selected new foods and related material culture, while keeping to an overall more traditional lifestyle (King 1984, 1999; Cool 2006; Locker 2007; Maltby 2007; van der Veen 2008; Cramp et al. 2011).

A number of excellent synthetic accounts of food consumption in Roman Britain from different methodological perspectives have recently been published, e.g. Grant (2007) on meat diet; Locker (2007) on fish; van der Veen (2008) on plants; Cool (2006) for a general overview and especially material culture. The contribution from bone chemistry, however, namely stable isotope analysis of bone collagen, is yet to be fully integrated into the academic debate. This is despite the success of the first application of the technique in Romano-British archaeology at Poundbury Camp Cemetery in Dorset, where the results indicated not only greater diversity in diet in the Roman period compared with the Iron Age, but also significant differences between high-status individuals (in lead coffins and mausolea) and 'simple' inhumations in earth graves or wooden coffins, suggesting that marine products were an elite food in Roman Britain (Richards et al. 1998).

Since the Poundbury study, the number of practitioners of dietary isotope analysis has increased considerably and, as a result, a much larger body of Iron Age and Roman-period carbon and nitrogen isotope data is now available-although these are usually published as individual case studies and in rather diverse places (Fuller et al. 2006; Jay \& Richards 2006, 2007; Müldner \& Richards 2007; Jay 2008; Cummings 2009; Lightfoot et al. 2009; Chenery et al. 2010, 2011; Cummings \& Hedges 2010; Redfern et al. 2010, 2012; Stevens et al. 2010, 2012; Müldner et al. 2011; Pollard et al. 2011; Cheung et al. 2012). A recent interdisciplinary project that explored population diversity in Roman Britain included isotopic approaches to diet in its research design (see Eckardt 2010).

The present study is an attempt to take stock and assess the contribution of the method to Romano-British archaeology so far. In doing so, I will concentrate on two questions: (1) do the isotope data indicate a general change in diet (i.e. a shift in site averages) from the Iron Age to the Roman period and, if so, what form did this shift take? (2) What can the data on intra-population variation tell us about dietary diversity in different groups of Romano-British society? New data for Roman York are presented and interpreted within the context of published results from other sites, in order to identify wider trends.

\section{Differences between Iron Age and Romano-British diet}

Since Richards et al. (1998) first identified systematic differences in the diet of late Iron Age and Roman-period humans at Poundbury, the field has seen a number of advances.

(C) Antiquity Publications Ltd. 
For example, greater emphasis is now placed on the observation that isotope values of different food types can vary significantly in time and space, due to factors such as climate or agricultural management practices (van Klinken et al. 2000; Hedges \& Reynard 2004). These 'baseline' fluctuations imply that isotope data from human consumers, when compared directly, may appear to vary between populations, even though the diets were essentially the same (see Jay \& Richards 2007; Stevens et al. 2012). The possibility of baseline change between the Iron Age and Roman period in Britain is a very real one: palaeoclimate records indicate that environmental conditions were slightly warmer and drier in the first to third centuries $\mathrm{AD}$ than before (the 'Roman Warm Period') and there were also a number of changes in land management, e.g. land clearance in the late Iron Age and Roman period (Dark 2000). These processes could well produce a small rise in plant carbon isotope ratios, which might be traceable in animal and human consumers (Heaton 1999; Hamilton et al. 2009). Any comparisons of human isotope data across the BC/AD divide must therefore account for possible environmental changes.

In order to monitor isotope baselines for individual sites, most specialists have taken to analysing bones of the principal food animals alongside the human samples. Herbivores especially are assumed to give averaged values of the local vegetation, providing a proxy not only for animal products in the diet but also, indirectly, for available plant foods (Hedges et al. 2004; Hedges \& Reynard 2007). This approach has the added advantage that data produced in different laboratories can be normalised. There are no published animal bone data from Poundbury that would allow monitoring the environmental baselines, and although two more recent case studies also report significant differences in carbon isotope values between Iron Age and Roman burials, their authors rightly pointed out that the number of their human or animal samples was probably too small for wide-reaching interpretations (Lightfoot et al. 2009; Redfern et al. 2010). It is nevertheless clear that there is a trend worth investigating here and the quantity of other Iron Age and Roman-period carbon and nitrogen isotope data allow us to do so.

The largest regional set of Iron Age and Roman-period isotope values is currently available from East Yorkshire, from the Iron Age cemetery of Wetwang Slack and the city of York (Jay \& Richards 2006; Müldner \& Richards 2007; Müldner et al. 2011, see Figure 1). New data for humans and herbivores from Roman York presented here (online supplement, Tables S1-2), brings the total to 234 humans and 75 herbivores. When the two time periods are compared, it is immediately apparent that the Roman-period humans are shifted towards more positive carbon isotope ratios $\left({ }^{13} \mathrm{C}\right)$ compared with the Iron Age samples (Figure 2). Their higher nitrogen isotope values $\left(\delta^{15} \mathrm{~N}\right)$, on the other hand, are largely matched by corresponding differences in the herbivores, suggesting that they were mainly due to changes in environmental factors or animal management (differences between human and herbivore averages for each period are: $1.1 \%$ o (carbon) and 4.8\%o (nitrogen) for Wetwang and $2.0 \%$ and $5.2 \%$ for York).

A survey of other data sets from across Britain, although mostly smaller in size, shows the same trend: Figure 3 displays the differences between average human isotope values and contemporaneous herbivores from the same area $\left(\Delta_{\text {human-herbivores }}\right)$ for all published Roman or Iron Age populations with appreciable numbers of faunal samples available (cattle and sheep/goat: $n \geqslant 10$; see caption to Figure 3 for details). The human dietary signals are thus

(C) Antiquity Publications Ltd. 
normalised for 'baseline variations' due to differences in the environment or the treatment of animals between sites or time periods. $\delta^{15} \mathrm{~N}$ offsets are variable, but because of the

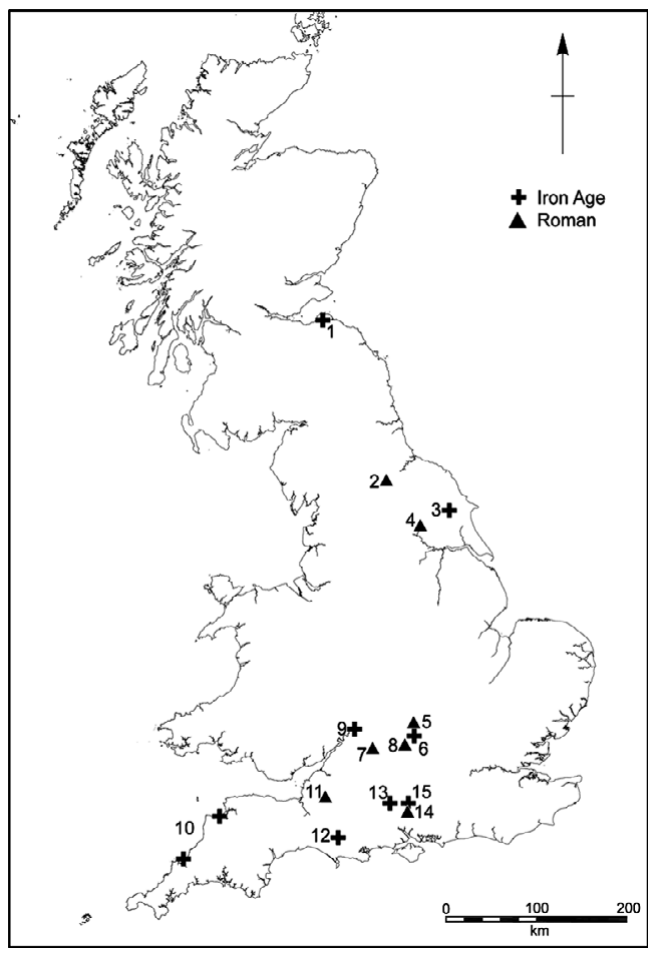

Figure 1. Map of the sites referred to in the text. Key: 1) Iron Age (IA) East Lothian sites; 2) Catterick; 3) Wetwang; 4) York; 5) Alchester; 6) Yarnton; 7) Cirencester, Stanton Harcourt, Horcott Quarry, Cotswold Community; 8) Gloucester; 9) IA Cornwall sites; 10) Glastonbury; 11) Poundbury and Dorset sites; 12) Danebury; 13) Winchester; 14) IA Hampshire sites. caveats in using faunal $\delta^{15} \mathrm{~N}$ as proxies for the plants consumed by humans (see Hedges \& Reynard 2007; Lightfoot \& Stevens 2012) and the complexity of some of the diets involved (see Müldner \& Richards 2007), these small isotopic differences should not be over-interpreted. A more obvious trend can be seen in the $\delta^{13} \mathrm{C}$ values: with few exceptions the Roman-period humans consistently display more positive values than their Iron Age counterparts. Although the actual differences between the two time periods are again only small (on average little more than $0.5 \%$ ), the number of sites involved and the sample sizes strongly suggest this is a genuine pattern. Because there is no indication, not even in the largest animal bone data sets assembled here, that this difference is linked to changes in environment or agricultural practices, the shift can best be explained by a widespread, significant change in human diet.

Even though a number of changes may have contributed to the observed shift in carbon isotope values, such as an abandonment of traditional foodways (e.g. horse meat) and the introduction of new foods (e.g. domestic fowl; see Cummings 2009; Lightfoot et al. 2009), it is most likely that, at the heart of the change, must have been the increased consumption of foods with very different, substantially higher $\delta^{13} \mathrm{C}$ than the traditional Iron Age fare. Such foods would require the smallest relative contribution to the diet in order to affect a visible change to the human isotope data (and consequently the least radical change in subsistence regime). Prime candidates to consider are therefore plants using the $\mathrm{C}_{4}$-photosynthetic pathway and marine foods. There are no native $\mathrm{C}_{4}$-cultigens in Britain, and although the first finds of millet date from the Roman period, these are so rare that they have been interpreted as 'exotic' imports, rather than widely available crops (see Müldner et al. 2011). As an explanation for a general dietary shift, $\mathrm{C}_{4}$-plants can therefore be all but ruled out. Small contributions of marine protein from inshore and anadromous fish or molluscs (particularly oysters), on the other hand, have been used to explain Roman-period isotope data from a number of urban sites (Müldner \& Richards 2007; Cummings 2009; Cummings \& Hedges 2010; Redfern et al. 2010; Cheung et al.

(C) Antiquity Publications Ltd. 




Figure 2. Comparison of human samples from Roman York and Iron Age Wetwang, Yorkshire, with average values for herbivores (cattle, sheeplgoat) and fish from other archaeological contexts in York (data: Jay \& Richards 2006; Müldner \& Richards 2007; Müldner et al. 2011; this publication). Error bars indicate 1s.d.

2012), a suggestion which is consistent with zooarchaeological evidence indicating a rise in importance of molluscs, fish and fish products in the diet (Cool 2006: 106-10; Grant 2007; Locker 2007). For clarity, it should be noted here that freshwater species and eel, although they occur regularly in Roman fishbone assemblages, cannot easily explain the observed isotope data. Available reference data indicates that their consumption should shift $\delta^{13} \mathrm{C}$ towards more negative, not more positive, values (see Müldner \& Richards 2007).

Although the fishbone record is affected by the usual problems of taphonomic and recovery bias, and total numbers are low, it is clear that marine products were transported over considerable distances to inland consumers, at least in south-east Britain, and were available not only in towns but also at villa sites and even some smaller rural settlements (Cool 2006; Locker 2007). By contrast, not just marine but wild foods in general are conspicuously scarce in Iron Age contexts and their increased use in the Roman period has therefore been attributed special significance, as indicating a break with tradition and possibly the adoption of a new 'Romanised' mindset (Dobney \& Ervynck 2007; Locker 2007; van der Veen 2008). In Iron Age populations, the contribution of marine foods to the diet that is indicated by the isotope data is generally non-existent, or at least too small to be measured (see Jay $\&$ Richards 2007). In the Roman period, it is still small, only just within the detection limits of the method, and the consumption of marine products appears to have been restricted to parts of the population. Nevertheless, the fact that any difference between the two periods registered at all in the human isotope signal, which is an extremely conservative dietary indicator, emphasises that the dietary change that occurred must have been very significant indeed. 


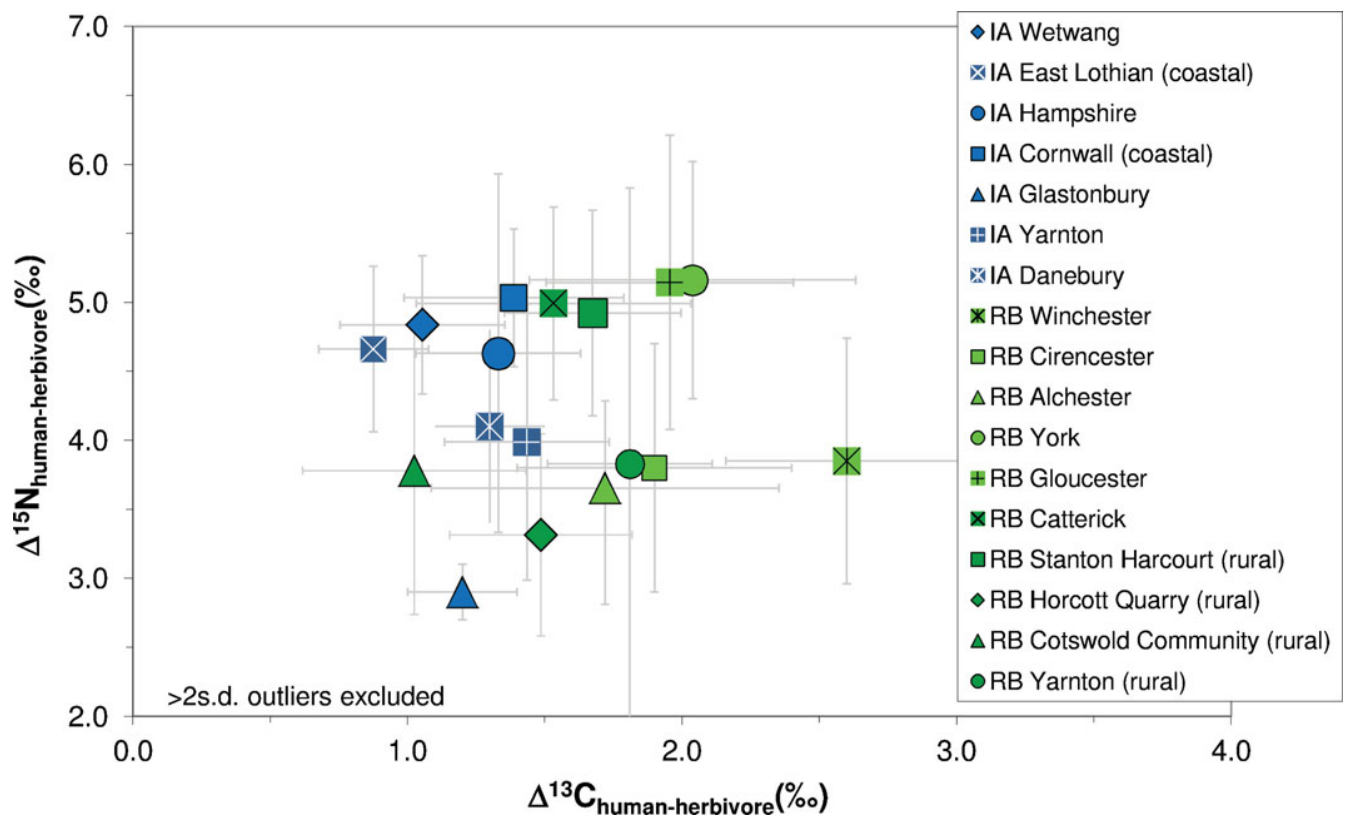

Figure 3. Average human-herbivore (cattle and sheep/goat) differences for Iron Age and Romano-British populations with sizeable herbivore baselines $(n \geqslant 10)$. Herbivore averages were calculated as: (cattle average + sheep/goat average)/2. Duplicate samples, humans aged $<6$ years and outliers $>2 \sigma$ were excluded. Error bars indicate $1 \sigma$ from the mean of the human samples.

Data sources and sample quantities: IA Wetwang: $n_{(\text {human })}=61, n_{\text {(berbivore })}=25$ (Jay \& Richards 2006); IA East Lothian: $n_{(\text {buman })}=24, n_{(\text {herbivore })}=24 ;$ IA Hampshire: $n_{(\text {buman })}=26, n_{(\text {berbivore })}=20 ;$ IA Cornwall: $n_{\text {buman }}=$ $24, n_{\text {(herbivore })}=15$ (Jay \& Richards 2007); IA Glastonbury: $n_{(\text {buman })}=11, n_{(\text {berbivore })}=12$ (Jay 2008); IA Yarnton: $n_{(\text {buman })}=27, n_{\text {(berbivore })}=24 ;$ Roman Britain $(R B)$ Yarnton: $n_{(\text {buman })}=5, n_{(\text {berbivore })}=19$ (Lightfoot et al. 2009); IA Danebury: $n_{\text {(buman })}=58, n_{\text {(berbivore })}=97$ (Stevens et al. 2010); $R B$ Catterick: $n_{(\text {buman })}=39, n_{(\text {berbivore })}=16($ Chenery et al. 2011); RB Winchester: $n_{(\text {buman })}=125 n_{\text {(berbivore })}=28$ (Cummings \& Hedges 2010); RB Cirencester: $n_{(\text {buman })}=$ 144; RB Alchester: $n_{(\text {buman })}=15 ;$ RB Stanton Harcourt: $n_{(\text {buman })}=27$, RB Horcott Quarry $n_{(\text {buman })}=22 ;$ RB Cotswold Community $n_{\text {buman }}=24, n_{\text {(berbivore) }}($ Cirencester + Alchester $)=33$ (Cummings 2009; Cheung et al. 2012); RB York: $n_{(\text {buman })}=172, n_{\text {(berbivore })}=50$ (Müldner \& Richards 2007; Müldner et al. 2011; this paper); RB Gloucester: $n_{(\text {buman })}$ $=45, n_{\text {(herbivore) }}=13$ (Chenery et al. 2010; Cheung et al. 2012). For dates of cemeteries, see Table S3.

This paper does not afford the space for an in-depth consideration of dietary variation between sites and one should probably not interpret the small differences between populations in Figure 3 far beyond the general diachronic trend. It is nevertheless interesting that the sites with the greatest human-herbivore differences are all larger towns (Cirencester, Gloucester, Winchester, York), conforming to the general expectation that more diverse foods were available in urban centres. Similarly, the smallest $\Delta^{13} \mathrm{C}$ are present at the rural settlements Horcott Quarry and Cotswold Community, and the small northern town of Catterick, which are most similar to the Iron Age sites and fit suggestions that rural areas, minor towns and the North may have been less affected by Roman influence. Nevertheless, it is important to note that no clear-cut patterns exist, just as other authors have observed considerable variability, especially between rural sites (Cool 2006; Locker 2007; van der Veen et al. 2008).

The data sets assembled here are of course not ideal. Because cremation was the dominant burial rite in late Iron Age and early Roman Britain, we are mainly comparing what are often (C) Antiquity Publications Ltd. 
unusual burials or disarticulated remains from the middle Iron Age (fourth to early first century BC) with populations from the middle and later Roman period (late second to fourth century $\mathrm{AD}$ ). We are thus missing the crucial centuries of the late Iron Age/Roman transition (see Table S3 for dates of cemeteries used). Nevertheless, the limited evidence we have from first-century $\mathrm{BC} / \mathrm{AD}$ humans, although without (robust) faunal baselines, confirms the general trend towards higher human $\delta^{13} \mathrm{C}$ values in the Roman period (Richards et al. 1998; Redfern et al. 2010).

\section{Dietary variation within Romano-British populations}

\section{Gender and status differences}

The Poundbury case study gave the first indication that there was significant dietary inequality between different groups in Romano-British society (Richards et al. 1998), a theme which a number of case studies have since pursued. Differences between the sexes appear to be relatively rare, but have been noted in the low-status group at Poundbury, at Queenford Farm (Fuller et al. 2006), Gloucester (Cheung et al. 2012) and Bainesse/Catterick (Chenery et al. 2011). These data suggest more marine protein or perhaps more diverse diets consumed by males, which could possibly be linked to their increased mobility compared with females (see Chenery et al. 2011). Interestingly, Redfern et al. (2010) indicate in their abstract that they found the opposite pattern at their Dorset sites, although this is then not discussed in the article itself.

Relatively few sites afford direct comparisons according to burial rite, although some interesting patterns emerge: Cummings (2009) observed that individuals buried in limestone coffins at Cirencester had more access to marine products than the majority of the population. At Lankhills/Winchester, Cummings \& Hedges (2010) note a number of trends, including higher $\delta^{13} \mathrm{C}$ of individuals in wooden coffins over simple earth burials and lower values of prone and possibly also crouched burials (the latter often interpreted as a vestige of earlier native rites, see Philpott 1991) compared to individuals in supine position. These results seem to confirm the suggestion by Richards et al. (1998) of a link between higher status and, perhaps, specifically Roman-style burials with marine food consumption.

At Roman York, the largest data set available, no such clear pattern exists. Although a number of individuals in sarcophagi and other elaborate containers have high isotope values which place them at the edge or even significantly outside the main field of samples, the majority of evidently high-status burials plot close to the population mean, indicating no systematic link between burial rite and a special diet (Figure 4). Nevertheless, the results demonstrate that another factor, besides status, needs to be taken into account when examining the relationship between diet and burial rite, and that is migration into Britain.

\section{Diet and mobility}

The York data set is unusual, because of the large number of individuals with evidently very atypical diets for York or even Roman Britain, which are indicated by outliers plotting more than two or even three standard deviations from the population mean (Figure 4). A number of these data are derived from tooth dentine rather than bone (see Table S2), reflecting 


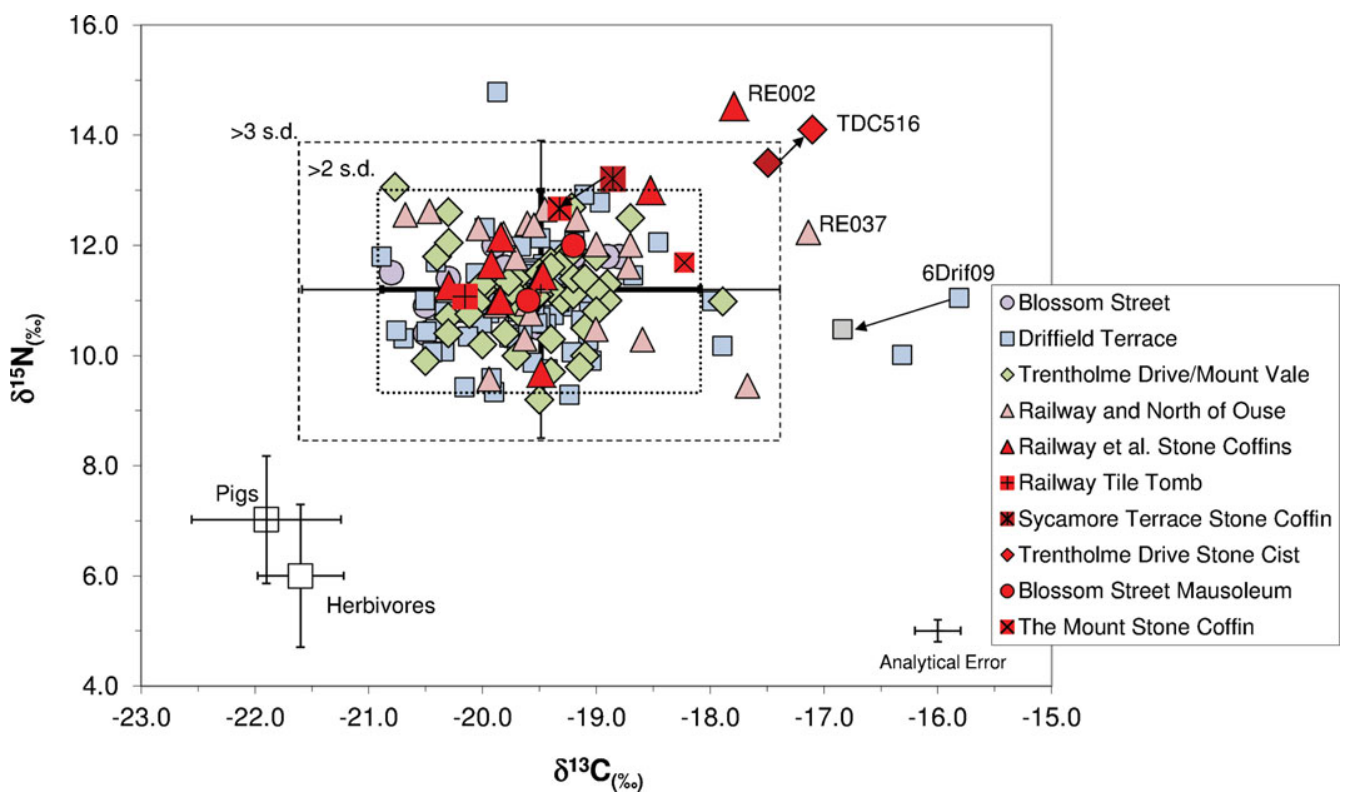

Figure 4. Carbon and nitrogen stable isotope data from Roman York indicating outliers and special burials. The stepped error bars and dotted/dashed lines delineate 2s.d. and 3s.d. Labels refer to individuals discussed in the text. Arrows connect dentine and rib values from the same individual (not all data shown) (data: Müldner \& Richards 2007; Müldner et al. 2011; this paper).

diet in childhood and, as has been argued elsewhere (Müldner et al. 2011), such extreme outliers are often better explained by incomers still exhibiting the dietary signals from their place of origin than by 'normal' dietary variation at the same site. Unlike strontium and oxygen, the isotopic systems more commonly employed in migration studies, carbon and nitrogen stable isotopes are not overly sensitive to variation between different geographical regions, and the large differences between some of the individuals and the main field must therefore indicate significant environmental or economic differences between their former residence and the place they died (e.g. Sealy et al. 1995; Dupras \& Schwarcz 2001). They can therefore be used to narrow down possible areas of origin of individual migrants (Cox et al. 2001; Müldner et al. 2011). For example, the carbon and nitrogen isotope values of many of the less extreme outliers at York, including, possibly, those only just outside the 2-standard deviation boundary, could be explained simply by environmental (i.e. isotope baseline) variations between different sites, in Britain or abroad. They do not necessarily imply that the diets of these individuals were, in themselves, substantially different from diet in York, which was based mainly on foods from a terrestrial $\mathrm{C}_{3}$-ecosystem as typical for large parts of temperate Europe (see Müldner et al. 2011). By contrast, the individuals at the extreme edges of the distribution in Figure 4 must have been used to very different diets prior to their arrival. Burial rite was not always documented, but at least two of these, sample numbers RE02 and TDC516, were evidently of high status, buried in a stone sarcophagus and a stone slab cist, respectively. Their tooth enamel oxygen isotope values, which reflect climate and geography of childhood residence, place them in the upper or, for TDC516, outside the usual range for individuals brought up in Britain and suggest origins in warm (C) Antiquity Publications Ltd. 


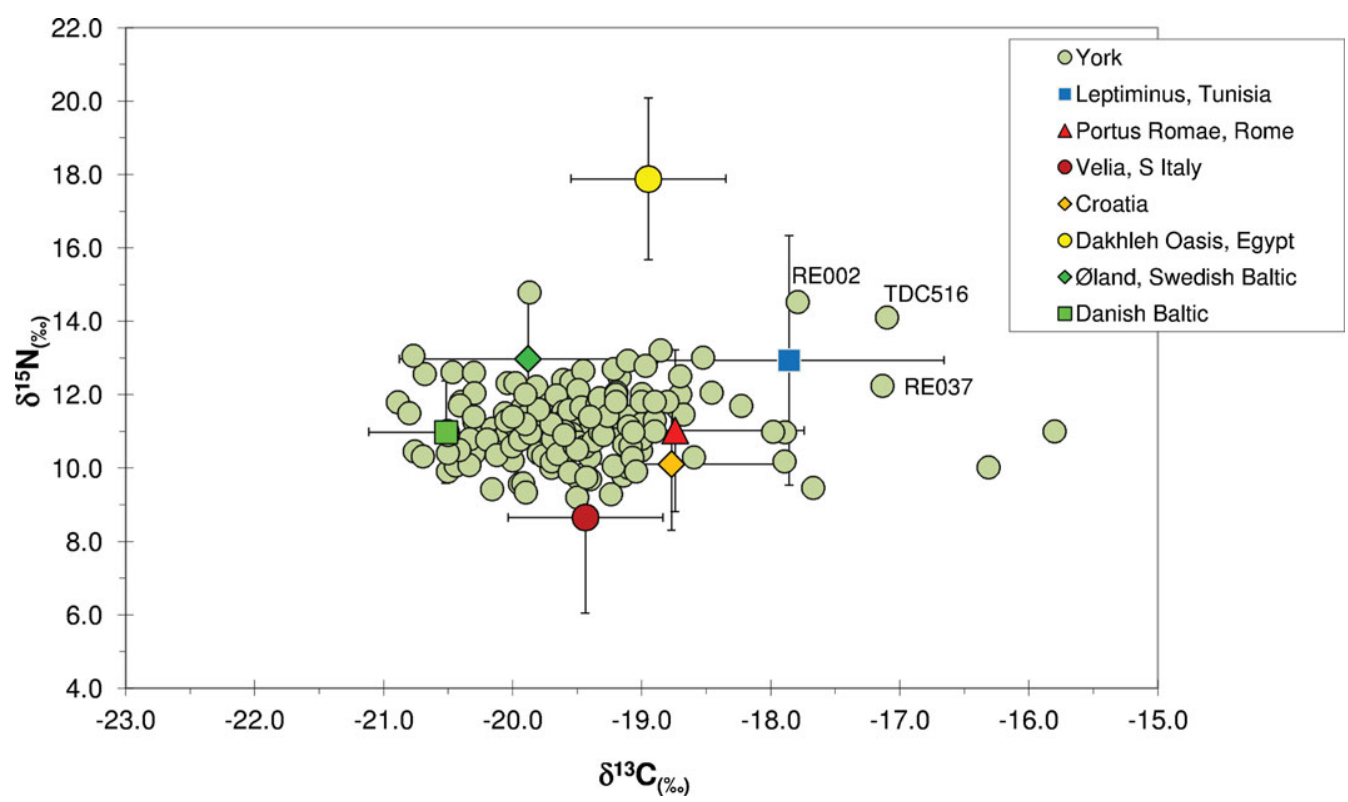

Figure 5. Stable isotope data from York in comparison with Roman-period data from different regions of the empire and beyond (individuals <6 years [where known] and extreme outliers removed; error bars indicate 2s.d.; data: Prowse et al. 2004; Dupras et al. 2008; Eriksson et al. 2008; Craig et al. 2009; Keenleyside et al. 2009; Crowe et al. 2010; Jørkov et al. 2010; Lightfoot et al. 2012).

or possibly more maritime climates (Leach et al. 2009, although it is possible that a marine contribution to their diet may have contributed to their elevated $\delta^{18} \mathrm{O}$, see Bowen et al. 2009). Befitting this, the unusually high $\delta^{13} \mathrm{C}$ and $\delta^{15} \mathrm{~N}$ recorded in their tooth dentine, which reflect diet around the same age or slightly later than the oxygen signal from the enamel, would normally be interpreted in terms of a diet rich in marine foods; although, such values could also be the result of consumption of $\mathrm{C}_{4}$-plants (or of animals with

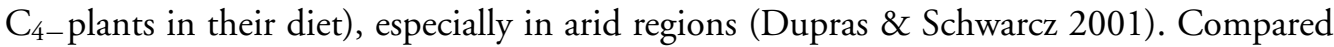
to available palaeodietary data from different regions of the Roman empire, they currently fit best with the population from Leptiminus, coastal Tunisia (Figure 5; Keenleyside et al. 2009), although this should not be taken as a secure attribution. The comparison with a North African assemblage nevertheless gives us an indication of how exotic the homelands of these two incomers may have been (see also Leach et al. 2010 for an example of an inhabitant of Roman York of probable African descent).

It follows from this discussion of the York data set that palaeodietary data, rather than just giving information about dietary variation between different social groups, can also reflect the diverse, even 'cosmopolitan' nature of society in a major urban centre, which received migrants, evidently of high and low status, even from far-flung corners of the empire. Although the isotope data do not suggest any consistent link between burial rite or status, diet and geographical origin, it is clear that these factors are key to the understanding of at least individual burials. 
As a provincial capital and important military base, York must have attracted its fair share of visitors and new citizens (Ottaway 2004) and it is therefore not necessarily surprising if the data from York stands out in comparison to most other sites. Nevertheless, if individuals with unusual isotopic signatures have so far only been observed in few other investigations (see Richards et al. 1998; Redfern et al. 2010; Pollard et al. 2011), this may partly be due to sample sizes and also sampling strategy. At York, most of the 'exotic' dietary data were obtained from dentine samples, reflecting diet in childhood or early adolescence, as opposed to the rib bone collagen, which was analysed at most other sites and is often preferred in dietary investigations because it is more representative of the later years in an individual's life (Sealy et al. 1995). Therefore, if individuals changed their diet to the local fare on arrival in Britain, they would, after some time, be indistinguishable from the local population. By comparing data from bone and dentine, we can, for example, identify TDC516 as a relatively recent arrival (bone and dentine values are effectively the same), while individual 6Drif09 (see Müldner et al. 2011) probably spent a number of years in York or an area with a similar diet: the $\delta^{13} \mathrm{C}$ of his rib is shifted significantly in the direction of a $\mathrm{C}_{3}$-plant based diet more typical of known European populations (Figure 5). While the results from York appear unusually diverse for now, only more regular analysis of dentine alongside bone collagen isotopes will put them into context, while advancing our understanding of diversity at different Romano-British sites.

\section{Conclusions}

This examination of available carbon and nitrogen isotope evidence from Roman Britain has confirmed findings from other methods of dietary reconstruction, namely that Britain's integration into the Roman empire did indeed effect a significant change in diet. Review of the data demonstrated small but consistent differences in $\delta^{13} \mathrm{C}$ between Roman-period and earlier Iron Age populations. Although these could be theoretically explained by an isotopic 'baseline shift' due to the 'Roman Warm Period' or innovations in land or animal management, this is not supported by available faunal 'control' samples. The observed changes are therefore best linked to the rise in aquatic and especially marine foods consumption which has been observed in the zooarchaeological record and is symptomatic of a general increase in dietary breadth compared to Iron Age Britain, which is recorded in both animal bone and plant assemblages (Cool 2006; Grant 2007; Locker 2007; van der Veen 2008). The fact that the transition is also traceable in the isotopic record, which is not very susceptible to small variations, demonstrates that it must have constituted a very significant change to the preceding period.

The suggestion of marine products as high-status foods, possibly reflecting the adoption of 'Roman' cultural values, is tentatively supported in a number of data sets, especially from towns, while there is also evidence for gender-specific dietary practices at some of the sites. The presence of long-distance migrants is demonstrated through a number of individuals with 'exotic' childhood diets in urban centres, especially York, and again appears as a significant change from the Iron Age. It illustrates the opening of the province to foreigners from across the empire and also demonstrates the usefulness of dietary indicators for addressing questions of mobility.

(C) Antiquity Publications Ltd. 
Over the last decade, dietary isotope analysis has come of age. With larger data sets becoming available, we can now move beyond individual case studies, as the method provides its own unique perspective on everyday life in Britain under Rome. At the same time, it offers increasingly exciting prospects for future investigations of culture change and its effects on past populations and individuals.

\section{Acknowledgements}

This research was funded by the AHRC under the 'Diaspora, Migrations, Identities' programme. Sincere thanks go to project members Carolyn Chenery, Hella Eckardt, Stephany Leach and Mary Lewis as well as to Tina Moriarty (sample preparations), the Natural History Museum (London), York Archaeological Trust and the Yorkshire Museum (sampling permissions). Colleen Cummings kindly enabled access to her unpublished DPhil thesis and Mandy Jay and three reviewers provided helpful comments on an earlier draft.

\section{References}

Bowen, G.J., J.R. EhLERINGER, L.A. CheSSON, A.H. Thompson, D.W. PODlesaK \& T.E. Cerling. 2009. Dietary and physiological controls on the hydrogen and oxygen isotope ratios of hair from mid- $20^{\text {th }}$ century indigenous populations. American Journal of Physical Anthropology 139: 494-504.

Chenery, C., G. Mưldner, J. Evans, H. Eckardt \& M. LEWIS. 2010. Strontium and stable isotope evidence for diet and mobility in Roman Gloucester, UK. Journal of Archaeological Science 37: 150-63.

Chenery, C., H. Eckardt \& G. MÜldner. 2011. Cosmopolitan Catterick? Isotopic evidence for population mobility on Rome's northern frontier. Journal of Archaeological Science 38: 1525-36.

Cheung, C., H. Schroeder \& R.E.M. Hedges. 2012. Diet, social differentiation and cultural change in Roman Britain: new isotopic evidence from Gloucestershire. Archaeological and Anthropological Science 4: 61-73.

CoOL, H.E.M. 2006. Eating and drinking in Roman Britain. Cambridge: Cambridge University Press.

Cox, G., J. Sealy, C. Schrire \& A. Morris. 2001. Stable carbon and nitrogen isotopic analyses of the underclass at the colonial Cape of Good Hope in the eighteenth and nineteenth centuries. World Archaeology 33: 73-97.

Craig, O.E., M. Biazzo, T.C. O’Connell, P. Garnsey, C. Martinez-Labarga, R. Lelli, L. Salvadei, G. Tartaglia, A. Nava, L. Reno, A. FiAMMENGHI, O. RickARDS \& L. BONDIOLI. 2009. Stable isotopic evidence for diet at the Imperial Roman coastal site of Velia ( $1^{\text {st }}$ and $2^{\text {nd }}$ centuries $\mathrm{AD})$ in southern Italy. American Journal of Physical Anthropology 139: 572-83.
Cramp, L.J.E., R.P. Evershed \& H. ECKARdT. 2011. What was a mortarium used for? Organic residues and cultural change in Iron Age and Roman Britain. Antiquity 85: 1339-52.

Crowe, F., A. Sperduti, T.C. O’Connell, O.E. Craig, K. Kirsanow, P. Germoni, R. Macchiarelli, P. Garnsey \& L. Bondioli. 2010. Water-related occupations and diet in two Roman coast communities (Italy, first to third century AD): correlation between stable carbon and nitrogen isotope values and auricular exostosis prevalence. American Journal of Physical Anthropology 142: 355-66.

Cummings, C. 2009. Meat consumption in Roman Britain: the evidence from stable isotopes, in J. Hendriks (ed.) TRAC 2008. Proceedings of the $18^{\text {th }}$ Annual Theoretical Roman Archaeology Conference, Amsterdam 2008: 73-83. Oxford: Oxbow.

Cummings, C. \& R. Hedges. 2010. Carbon and nitrogen stable isotope analyses, in P. Booth, A. Simmonds, A. Boyle, S. Clough, H.E.M. Cool \& D. Poore (ed.) The Late Roman cemetery at Lankhills, Winchester. Excavations 2000-2005 (Oxford Archaeology Monograph 10): 411-21. Oxford: Oxford Archaeology.

DARK, P. 2000. The environment of Britain in the first millenium $A D$. London: Duckworth.

Dobney, K. \& A. ERVyNCK. 2007. To fish or not to fish? Evidence for the possible avoidance of fish consumption during the Iron Age around the North Sea, in C. Haselgrove \& T. Moore (ed.) The later Iron Age in Britain and beyond: 402-18. Oxford: Oxbow.

DUPRAS, T.L. \& H.P. SCHWARCZ. 2001. Strangers in a strange land: stable isotope evidence for human migration in the Dakhleh Oasis, Egypt. Journal of Archaeological Science 28: 1199-1208. 
Dupras, T.L., H. SCHWARCZ \& S.I. FAIRGRIEVE. 2008. Dining in the Dakhleh Oasis: determining diet from stable isotopes, in M.F. Wiseman \& B.E. Parr (ed.) The Oasis papers 2. Proceedings of the $2^{\text {nd }}$ International Conference of the Dakhleh Oasis Project: 119-28. Oxford: Oxbow.

ECKARDT, H. 2010. A long way from home: diaspora communities in Roman Britain, in H. Eckardt (ed.) Roman diasporas: archaeological approaches to mobility and diversity in the Roman empire (Journal of Roman Archaeology Supplementary Series 78): 99-130. Portsmouth (RI): Journal of Roman Archaeology.

Eriksson, G., A. Linderholm, E. Fornander, M. Kanstrup, P. Schoultz, H. Olofsson \& K. LIDÉN. 2008. Same island, different diet: cultural evolution of food practice in Öland, Sweden, from the Mesolithic to the Roman period. Journal of Anthropological Archaeology 27: 520-43.

Fuller, B.T., T.I. Molleson, D.A. Harris, L.T. Gilmour \& R.E.M. Hedges. 2006. Isotopic evidence for breastfeeding and possible adult dietary differences from Late/Sub-Roman Britain. American Journal of Physical Anthropology 129: 45-54.

Grant, A. 2007. Domestic animals and their uses, in M. Todd (ed.) A companion to Roman Britain: 371-92. Oxford: Blackwell.

Hamilton, J., R.E.M. Hedges \& M. Robinson. 2009. Rooting for pigfruit: pig feeding in Neolithic and Iron Age Britain compared. Antiquity 83: 998-1011.

HeAton, T.H.E. 1999. Spatial, species and temporal variations in the ${ }^{13} \mathrm{C} /{ }^{12} \mathrm{C}$ ratios of $\mathrm{C}_{3}$-plants: implications for palaeodiet studies. Journal of Archaeological Science 26: 637-49.

Hedges, R.E.M. \& L.M. Reynard. 2007. Nitrogen isotopes and the trophic level of humans in archaeology. Journal of Archaeological Science 34: 1240-51.

Hedges, R.E.M., R.E. Stevens \& M.P. Richards. 2004. Bone as a stable isotope archive for local climatic information. Quaternary Science Reviews 23: 959-65.

JAY, M. 2008. Iron Age diet at Glastonbury Lake Village: the isotopic evidence for negligible aquatic resource consumption. Oxford Journal of Archaeology 27: 201-16.

JAY, M. \& M.P. Richards. 2006. Diet in the Iron Age cemetery population at Wetwang Slack, East Yorkshire, UK: stable carbon and nitrogen isotope evidence. Journal of Archaeological Science 33: 653-62.

- 2007. British Iron Age diet: stable isotopes and other evidence. Proceedings of the Prehistoric Society 73: 169-90.
JøRKOV, M.L.S., L. JøRGENSEN \& N. LYNNERUP. 2010. Uniform diet in a diverse society. Revealing new dietary evidence of the Danish Roman Iron Age based on stable isotope analysis. American Journal of Physical Anthropology 143: 523-33.

KeEnleyside, A., H. Schwarcz, L. Stirling \& N. BEn LAZREG. 2009. Stable isotopic evidence for diet in a Roman and Late Roman population from Leptiminus, Tunisia. Journal of Archaeological Science 36: 51-63.

KING, A.C. 1984. Animal bones and the dietary identity of military and civilian groups in Roman Britain, Germany and Gaul, in T.F.C. Blagg \& A.C. King (ed.) Military and civilian in Roman Britain: cultural relationships in a frontier province (British Archaeological Reports British series 136): 187-217. Oxford: British Archaeological Reports.

- 1999. Diet in the Roman world: a regional inter-site comparison of the mammal bones. Journal of Roman Archaeology 12: 168-202.

van Klinken, G.J., M.P. Richards \& R.E.M. HEDGES. 2000. An overview of causes for stable isotopic variations in past European human populations: environmental, ecophysiological, and cultural effects, in S.H. Ambrose \& M.A. Katzenberg (ed.) Biogeochemical approaches to palaeodietary analysis: 39-63. New York: Kluwer Academic/Plenum.

LeACH, S., M. LeWIS, C. Chenery, G. Müldner \& H. ECKHARDT. 2009. Migration and diversity in Roman Britain: a multidisciplinary approach to the identification of immigrants in Roman York, England. American Journal of Physical Anthropology 140: 546-61.

Leach, S., H. EcKardt, C. Chenery, G. Müldner \& M. LEWIS. 2010. A lady of York: migration, ethnicity and identity in Roman Britain. Antiquity 84: 131-45.

Lightfoot, E. \& R.E. STEVENS. 2012. Stable isotope investigations of charred barley (Hordeum vulgare) and wheat (Triticum spelta) grains from Danebury Hillfort: implications for palaeodietary reconstructions. Journal of Archaeological Science 39: 656-62.

Lightfoot, E., T.C. O'Connell, R.E. Stevens, J. Hamilton, G. Hey \& R.E.M. Hedges. 2009. An investigation into diet at the site of Yarnton, Oxfordshire, using stable carbon and nitrogen isotopes. Oxford Journal of Archaeology 28: 301-22.

Lightfoot, E., M. Šlaus \& T.C. O’Connell. 2012. Changing cultures, changing cuisines: cultural transitions and dietary change in Iron Age, Roman and early medieval Croatia. American Journal of Physical Anthropology 148: 543-56.

LOCKER, A. 2007. In piscibus diversis: the bone evidence for fish consumption in Roman Britain. Britannia 38: $141-80$.

(C) Antiquity Publications Ltd. 


\section{Gundula Müldner}

Maltby, M. 2007. Chop and change: specialist cattle carcass processing in Roman Britain, in B. Croxford, N. Ray, R. Roth \& N. White (ed.) TRAC 2006. Proceedings of the $16^{\text {th }}$ Annual Theoretical Roman Archaeology Conference, University of Cambridge, 24-25 March 2006: 59-76. Oxford: Oxbow.

Mattingly, D. 2004. Being Roman: expressing identity in a provincial setting. Journal of Roman Archaeology 17: 5-25.

- 2006. An Imperial possession: Britain in the Roman empire. London: Penguin.

MÜLDNER, G. \& M.P. Richards. 2007. Stable isotope evidence for 1500 years of human diet at the city of York, UK. American Journal of Physical Anthropology 133: 682-97.

Müldner, G., C. Chenery \& H. Eckardt. 2011. The 'Headless Romans': multi-isotope investigations of an unusual burial ground from Roman Britain. Journal of Archaeological Science 38: 280-90.

OTtaWaY, P. 2004. Roman York. Stroud: Tempus.

PHILPOTT, R. 1991. Burial practices in Roman Britain. A survey of grave treatment and furnishing $A D$ 43-410 (British Archaeological Reports British series 219). Oxford: Tempus Reparatum.

Pollard, A.M., P. Ditchfield, J.S.O. McCullagh, T.G. Allen, M. Gibson, C. Boston, S. Clough, N. MarqueZ-Grant \& R.A. Nicholson. 2011. 'These boots were made for walking': the isotopic analysis of a $\mathrm{C}_{4}$ Roman inhumation from Gravesend, Kent, UK. American Journal of Physical Anthropology 146: 446-56.

Prowse, T., H.P. SchWarcz, S. SAunders, R. MACCHIARELli \& L. BONDIOLI. 2004. Isotopic paleodiet studies of skeletons from the Imperial Roman-age cemetery of Isola Sacra, Rome, Italy. Journal of Archaeological Science 31: 259-72.
Redfern, R.C., C. Hamlin \& N. Beavan-Athfield. 2010. Temporal changes in diet: a stable isotope analysis of late Iron Age and Roman Dorset, Britain. Journal of Archaeological Science 37: 1149-60.

Redfern, R.C., A.R. Millard \& C. Hamlin. 2012. A regional investigation of subadult dietary patterns and health in late Iron Age and Roman Dorset, England. Journal of Archaeological Science 39: 1249-59.

Richards, M.P., R.E.M. Hedges, T.I. Molleson \& J.C. VoGEL. 1998. Stable isotope analysis reveals variations in human diet at the Poundbury Camp Cemetery Site. Journal of Archaeological Science 25: 1247-52.

Sealy, J., R. Armstrong \& C. Schrire. 1995. Beyond lifetime averages: tracing life-histories through isotopic analysis of different calcified tissues from archaeological human skeletons. Antiquity 69: 290-300.

Stevens, R.E., E. Lightfoot, J. Hamilton, B. Cunliffe \& R.E.M. Hedges. 2010. Stable isotope investigations of the Danebury Hillfort pit burials. Oxford Journal of Archaeology 29: 407-28.

Stevens, R.E., E. LightFoot, T. Allen \& R.E.M. Hedges. 2012. Palaeodiet at Eton College rowing course, Buckinghamshire: isotopic changes in human diet in the Neolithic, Bronze Age, Iron Age and Roman periods throughout the British Isles. Archaeological and Anthropological Science 4: 167-84. doi: 10.1007/s12520-012-0089-0.

VAN DER VEEN, M. 2008. Food as embodied material culture: diversity and change in plant food consumption in Roman Britain. Journal of Roman Archaeology 21: 83-110.

Webster, J. 2001. Creolising Roman Britain. American Journal of Archaeology 105: 209-29.

Received: 24 February 2011; Accepted: 9 May 2011; Revised: 5 July 2012

(C) Antiquity Publications Ltd. 